\title{
Do Course-Based Service Learning Programs Offer More Benefits to Students than Non-Course-Based Programs? The Research Says "Yes"
}

\author{
William Walker ${ }^{1} \&$ Cynthia Walker ${ }^{2}$ \\ ${ }^{1}$ Institute for Family Preservation, Millbrook, Alabama, USA \\ ${ }^{2}$ Interdisciplinary Studies, Faulkner University, Montgomery, Alabama, USA \\ Correspondence: Cynthia Walker, Interdisciplinary Studies, Faulkner University, Montgomery AL 36109. Tel: \\ 1-334-386-7305.
}

Received: September 5, 2018

Accepted: September 28, $2018 \quad$ Online Published: November 6, 2018

doi:10.5539/jel.v7n6p197

URL: https://doi.org/10.5539/jel.v7n6p197

\begin{abstract}
This article examines the qualitative and quantitative differences between course-based service learning programs and non-course-based service programs at the post-secondary level. A review of the research to date reveals greater benefits for students who participate in course-based community service compared to participation in non-course-based service. The course-based model's cognitive component of organized reflection appears to be the key contributing factor that produces benefits superior to the non course-based approach, both in number and quality. Based on these findings, post-secondary institutions using non-course-based service learning program should consider changing to the course-based model.
\end{abstract}

Keywords: course-based community service, non-course-based community service, service learning

\section{Introduction}

Post-secondary community service programs began when students were encouraged by their respective colleges and universities to provide volunteer services to local community organizations. The intent was to enhance student learning by allowing students to gain experience in applying classroom skills to non-classroom settings. Over time, a more specific model evolved from the general community service model, called service learning.

Service learning is a type of course-based experiential learning that emphasizes benefits for the student as much as for the recipient. These benefits to the student are the result of intentionally designed course objectives intended to promote student learning and development through student community service and action (Jacoby, B., 1996; Howard, J. 2001).

Today, both forms of these service programs (course-based and non-course-based) continue to be used by colleges and universities. The result is students who complete at a post-secondary institution are allowed ample opportunities to make an impact on their communities, whether through course-based or non-course-based opportunities.

The issue of concern is that the research on student community service makes the case that the benefits to the student are more numerous for the course-based community service model, compared to the non-course-based service model. This raises two important questions: 1) are these differences significant enough for the course-based model to be considered more beneficial to the student than the non-course based model, and 2) if the course-based service model results in more benefit to the student, do post-secondary institutions which employ the non-course-based model do their students a disservice by doing so?

\section{The Two Models Defined and Compared}

\subsection{Non-Course-Based Model}

Specific definitions of the student community service model (non-course-based) and service-learning (course-based) model were developed by "Learn and Serve" in cooperation with the Corporation for National and Community Service (Gray, 2009). As defined by Learn \& Serve, "student community service" is non-curriculum-based community service activities recognized or arranged through the school that can be 
performed at any time for any reason. Of note community service generally does not include explicit learning objectives or organized reflection or critical analysis activities.

Non-coursed-based community service can be likened to volunteering. The emphasis is on the people being helped and the service being offered. Examples of service activities could include cleaning up a local park, visiting the elderly, or collecting and distributing food to those in need. This model does not include learning objectives or organized discussion activities for the students who participate.

\subsection{Course-Based-Model}

In contrast, "service-learning" is defined as curriculum-based community service that integrates classroom instruction with community service activities. The service must: 1) be organized in relation to an academic course or curriculum; 2) have clearly stated learning objectives; 3) assist students in drawing lessons from the service through regularly scheduled, organized reflection or critical analysis activities, such as classroom discussions, presentations, or directed writing (Gray, 2009).

\subsection{Differences Between the Models}

A key difference between the two approaches is that course-based service learning activities are embedded within specific classes or other formal learning settings that have carefully spelled out learning objectives designed to benefit the student participant. In contrast, the benefits of the non-course-based community service model are focused exclusively on the service recipients, not the student. The student may receive some benefits by developing an understanding regarding how their service makes a difference in the lives of the service recipients, but these benefits are more happenstance than intentional.

Another difference is the course-based model places emphasis on students making application of classroom academic principles to life situations outside the classroom (Howard, 2001). Failure to make a connection between the teachings in the classroom and 'real life' relevancy and application often results in a disconnect for the student. In turn, this disconnect can result in a type of motivation-related boredom for the student. Hedin (1989) asserted that this boredom results from the "unfathomable gap between the curriculum and their everyday lives." Hedin believes service learning affords students the "opportunity to apply academic learning to real human needs and to make the knowledge gained usable in one's thinking beyond the situation in which the learning occurred."

\subsection{Organized Reflection: The Most Critical Difference}

Is there a specific component of the course-based model not found in the non-course-based model that makes the course-based model more beneficial to the student? There is evidence that the cognitive component of organized reflection, a component not found in non-course-based service, is a critical key contributor to the student-received benefits of community service (Eyler, 2002). Reflection is believed to be a key requirement for individual learning and the application of learning (Dewey, 1933; Kolb, 1984; Reynolds \& Vince, 2004). Reflection, in the context of service experiences, can be defined as the "intentional consideration of an experience in light of particular learning objectives" (Hatcher \& Bringle, 1997). The goal of reflection is to help the student make sense of what they are seeing and doing.

Learning theory research has established that for an activity, idea, or concept to be assimilated into a learner's value system, the activity, idea or concept must make 'sense' (i.e., have meaning) (Kember, Ho, \& Hong, 2008). Reflection promotes personal understanding and meaning by integrating unapplied, abstract head knowledge with "personal, palatable experience" (Bringle \& Hatcher, 1999), with the result being student learning that is "deepened and strengthened."

Reflection is best applied using specific learning activities (Gay \& Kirkland, 2003). These activities can include the use of student portfolios, presentations, journals, poem writing, written responses to readings, group discussions and the like (Silberman, 1996). In facilitating organized reflection, these activities appear to provide the critical link between the service and the learning in the course-based model. The process of reflecting on the experience allows the service experience to become a learning opportunity. Only when students are provided opportunities to reflect on their experience will they begin making the connection between their work in the classroom and that in the community (Leeward Community College, n.d.).

Course-based service learning, therefore, weds the academic world with the practical, giving the student more opportunities to integrate and elaborate on their knowledge. These opportunities of integration and elaboration increase the likelihood that theoretical knowledge is transferred to actual practice followed by an understanding of how one's service has made a difference in both the student and the recipient. These benefits are primarily the 
result of the classroom reflection activities associated with the course-based service model. This critical component of reflection is neither a focus nor a concern of the non-course-based service model.

\subsection{Student Benefits of Each Model}

Volunteerism using a non-course-based model has been positively associated with several measures of physical and mental health.

Non-course-based community service is associated with the important area of adolescent development and functioning known as subjective well-being. Subjective well-being is a person's subjective cognitive and affective evaluations of their lives (Diener, 2000). Subjective well-being is intrinsically linked to life satisfaction. In turn, low life satisfaction is associated with increased levels of social and psychological problems while high levels of life satisfaction are positively associated with higher levels of social and psychological well-being (Park, 2004). Participation in non-course-based community service has been found to act as a moderating variable between high and low scores on multiple measures of positive well-being (Macllvaine, Nelson, Stewart, \& Stewart, 2014). Adolescents participating in community service evidenced higher levels of positive well-being when compared to those not participating in community service (Park, 2004).

Perhaps the least desirable consequence of adolescent poor subjective well-being is antisocial behavior. Youth antisocial behavior is a significant societal problem, costing states a combined 6 billion dollars per year on youth incarceration alone (Justice, 2009).

Adolescent positive well-being has been found to be associated with decreased antisocial behavior in adolescents (Park, 2004). Youth participation in general volunteer community service activities has been found to affect antisocial behavior. Hart, Atkins \& Ford (1998) found that when youth from impoverished neighborhoods participated in community volunteer activities levels of anti-social behavior decreased accordingly. As well, the authors found that community volunteerism was associated with increased levels of positive moral identity among the participants. Community service appears to have a strengthening effect on adolescent self-concept and image, which in turn decreases negative self-perception and the frustration and anger related to it - too often expressed in antisocial behavior.

Still, other studies have found positive associations between general community service and physical health (Moen, Dempster \& Williams, 1992) and mental health (Pancer \& Pratt, 1999) when compared to non-volunteering controls.

Since course-based service includes the same volunteer service activities as non-course-based services, it is intuitive to assume that course-based community service includes all the same benefits associated with the non-course-based model. The question is, are there significant differences, both in quantity and quality, found in the course-based model that is not found in the non-course-based model?

There is a consistent body of research supporting the student benefits of course-based service learning that are not associated with non-course-based community service. For example, when academic study in philosophy and theology was combined with community service, students reported altered career aspirations and "perceived themselves to be significantly impacted" as a result of the experience (Seider, Gillmor, \& Rabinowicz, 2011). The same authors found that students participating in course-based service learning evidenced improved academic skills such as problem analysis, critical thinking, logical reasoning, detailed observation, issue identification and higher and more complex thinking skills. Billig, Root \& Jesse (2005) found course-based service learning participation associated with increased personal, interpersonal and social development, along with increased motivation, student engagement, and school attendance.

Other research has found course-based service learning associated with increased student capacity to learn and retain school materials (Eyler, Root, \& Giles, 1998), increased personal motivations to learn (Cohen \& Kinsey, 1994) and increased complexity in analysis of both causes and solutions to social problems (Eyler \& Giles, 1999).

In a six year longitudinal study (Astin \& Vogelgesang, 2006), course-based service learning participation contributed to long-term student political and community involvement, especially when the service-learning was supported by faculty led reflection

A recent meta-analysis by Celio, Durlak, and Dymnicki (2011) examined 62 studies involving 11,837 students. Course-based service learning was associated with gains in five outcome areas including academic performance, civic engagement, social skills, attitudes toward self and attitudes toward school and learning, when compared to non-participating controls. 


\subsection{Service Learning Versus Community Service Head-To-Head}

The authors located only two studies in the literature where community service was compared to service learning head-to-head on specific outcome measures. In examining leadership life skill development in adolescents, Stafford, Boyd \& Lindner (2003) placed students in control, non-course-based \& course-based groups. The service learning group included trained facilitators who provided oral and written reflection activities immediately after the completion of the service project, while the other two groups included no organized reflection. Results showed that students in the course-based group had significantly higher levels of self-perceived personal leadership and community contribution skills compared to the students in the non-course based group and the control group.

In the largest study to date differences in outcome effectiveness were compared between course-based and non-course-based community service participation (Astin, Vogelgesang, Ikeda, \& Yee, 2000). Twenty-two thousand students from 19 U.S. colleges/universities were compared on a number of outcome variables including academic performance, values, self-efficacy, leadership, and career plans. The authors found that participation in course-based community service made a unique contribution over and above participation in non-course-based service on a number of outcome variables. Course-based community service was positively associated with GPA, writing skills and critical thinking skills over and above the contribution of non-course-based service. Course-based service was also associated with higher scores on measures of the construct of 'values' including the promotion of racial understanding, activism, and social self-efficacy compared to non-course-based participation. Regarding outcomes measuring leadership, course-based service had a positive effect for the outcome variables measuring leadership ability and leadership activities which the non-course model did not.

When the authors of this study sought to identify what specific factor(s) appeared to contribute the most to the greater efficacy of course-based community service they found it was "the opportunity to 'process' the service experience with other students" (Astin, Vogelgesang, Ikeda, \& Yee, 2000). The authors concluded that it was the "joint reflection by students on the service experience [that] entirely explains the positive effects" found in students participating in the service learning experiences verses students who participated in community service experiences.

\section{Discussion and Conclusions}

Although non-course-based community service can lead to some degree of transformative learning, this connection becomes explicit in course-based service. Course-based service offers the opportunity of organized reflection by student participants on the service activity itself, while non-course-based service does not. The literature finds it is this opportunity and experience of classroom organized reflection on the service experience that mediates the degree and quality of positive student outcome measures and learning.

Schools that implement community service requirements for students would do well to understand the important difference between course-based community service programs and non-course-based service programs. It is the opportunity for organized reflection activities between students, as well as between students and instructors, that gives course-based service a clear advantage to the student over non-course-based community service.

In the development of any service experience program a priority should be placed on integrating the acts of service with regular and organized learning activities that promote student reflection and analysis of the service experience itself. While non-course-based community service can be of some benefit, it is course-based service learning, with its organized reflection, that results in the most beneficial student service experiences.

Despite the limited student benefits of participating in non-course-based community service, the benefits to students who engage in course-based service learning appear to be superior in both quality and quantity. Because so, course-based service learning should be the preferred mode of service experiences and programs in higher education.

\section{References}

Astin, A. W., \& Vogelgesang, L. (2006). Understanding the effects of service-learning: A study of students and faculty. Los Angeles, CA: The Higher Education Research Institute.

Astin, A., Vogelgesang, L., Ikeda, E., \& Yee, J. (2000). How service learning affects student (pp. 1-128, Rep.). Los Angeles, CA: The Higher Education Research Institute.

Billig, S., Root, S., \& Jesse, D. (2005). The impact of participation in service-learning on high school students' civic engagement. Denver: RMC Research Corporation. 
Bringle, R., \& Hatcher, J. (1999). Reflection in Service Learning: Making Meaning of Experience. Educational Horizons, 77(4), 179-185. Retrieved from http://www.jstor.org/stable/42926911

Celio, C., Durlak, J., \& Dymnicki, A. (2011). A meta-analysis of the impact of service-learning on students. Journal of Experiential Education, 34(2), 164-181. https://doi.org/10.1177/105382591103400205

Cohen, J., \& Kinsey, D. (1994). "Doing good" and scholarship: A service-learning study. Journalism Educator, 48(4), 4-14. https://doi.org/10.1177/107769589304800402

Dewey, J. (1933). How we think: A restatement of the relation of reflective thinking to the educative process. Boston, MA: D.C. Heath.

Diener, E. (2000). Subjective well-being: The science of happiness and a proposal for a national index. American Psychologist, 55, 34-43. https://dx.doi.org/10.1037/0003-066X.55.1.34

Eyler, J. (2002). Reflection: Linking service and learning_linking students and communities. Journal of Social Issues, 58(3), 517-534. https://doi.org/10.1111/1540-4560.00274

Eyler, J. S., Root, S., \& Giles, D. E. Jr. (1998). Service-Learning and the development of expert citizens: Service-learning and cognitive science. In R. G. B. \& D. K. Duffy (Eds.), With service in mind: Concepts and models for service-learning in psychology. Washington DC: American Association for Higher Education.

Eyler, J., \& Giles, D. (1999). Where's the learning in service-learning? San Francisco, CA: Jossey-Bass.

Gay, G., \& Kirkland, K. (2003). Developing cultural critical consciousness and self-reflection in preservice teacher education. Theory into Practice, 42, 181-187. https://doi.org/10.1207/s15430421tip4203_3

Gray, M. (1996). National learn and serve evaluation-RAND/UCLA study. Message posted on the Service-learning Listserve.

Hart, D., Atkins, R., \& Ford, D. (1998). Urban America as a context for the development of moral identity in adolescence. Journal of Social Issues, 54, 513-530. https://doi.org/10.1111/j.1540-4560.1998.tb01233.x

Hatcher, J., \& Bringle, R. (1997). Reflections: Bridging the gap between service and learning. Journal of College Teaching, 45, 153. https://doi.org/10.1080/87567559709596221

Hedin, D. (1989). The power of community service. Proceedings of the Academy of Political Science, 37(2), 201-213. https://doi.org/10.2307/1173962

Howard, J. (2001). Michigan journal of community service-learning: Service-learning course design workbook. Ann Arbor, MI: OCSL Press.

Jacoby, B. (Ed.). (1996). Service-learning in higher education: Concepts and practices. San Francisco, CA: Jossey-Bass.

Justice Policy Institute. (2009). The costs of confinement: Why good juvenile justice policies make good fiscal sense. $\quad$ Retrieved from http://www.justicepolicy.org/images/upload/09_05_rep_costsofconfinement_jj_ps.pdf

Kember, D., Ho, A., \& Hong, C. (2008). The importance of establishing relevance in motivating student learning. Active Learning in Higher Education, 9, 249-263. https://doi.org/10.1177/1469787408095849

Kolb, D. (1984). Experiential learning: Experience as the source of learning and development. Englewood Cliffs, N.J.: Prentice-Hall, Inc.

Leeward Community College. (n.d.). Using reflection. In Service learning handbook. Retrieved from https://emedia.leeward.hawaii.edu/servicelearning/reflection.htm

MacIlvaine, W., Nelson, L., Stewart, J., \& Stewart, W. (2014). Association of strength of community service to personal well-being. Community Mental Health Journal, 50(5), 577-582. https://doi.org/10.1007/s10597-013-9660-0

Moen, P., Dempster, D., \& Williams, R. (1992). Successful aging: A life course perspective on women's multiple roles and health. Journal of Social Science, 1612-1628.

Pancer, S. M., \& Pratt, M. W. (1999). Social and family determinants of community service involvement in Canadian youth. In M. Youniss \& J. Youniss (Eds.), Roots of civic identity: International perspectives on community service and activism in youth (pp. 32-55). New York: Cambridge University Press. 
Park, N. (2004). The role of subjective well-being in positive youth development. The Annals of the American Academy of Political and Social Science, 591, 25-39. https://doi.org/10.1177/0002716203260078

Reynolds, M., \& Vince, R. (2004). Critical management education and action-based learning: Synergies and contradictions. Academy of Management: Learning \& Education, 3, 442-456. https://doi.org/10.5465/amle.2004.15112552

Seider, S., Gillmor, S., \& Rabinowicz, S. (2011). The impact of community service learning upon the worldviews of business majors versus non-business majors at an American university. Journal of Business Ethics, 98, 485-503. https://doi.org/10.1007/s10551-010-0589-8

Silberman, M. (1996). Active learning: 101 strategies to teach any subject. Des Moines, IA: Prentice-Hall.

Stafford, J., Boyd, B., \& Lindner, J. (2003). Community service versus service-learning: Which is best for 4-H? Journal of Extension, 41(6).

\section{Copyrights}

Copyright for this article is retained by the author, with first publication rights granted to the journal.

This is an open-access article distributed under the terms and conditions of the Creative Commons Attribution license (http://creativecommons.org/licenses/by/4.0/). 